\title{
Insulin resistance in children and adolescents - aetiology, complications and diagnostic methods
}

\author{
Insulinooporność u dzieci i młodzieży - przyczyny, powikłania i metody rozpoznania
}

\author{
${ }^{1}$ Department of Paediatric Endocrinology and Paediatrics, Children's Teaching Hospital - University Clinical Centre of the Medical University of Warsaw, Warsaw, Poland \\ 2 Department of Paediatrics and Endocrinology, Medical University of Warsaw, Warsaw, Poland \\ ${ }^{3}$ Department of Clinical Dietetics, Medical University of Warsaw, Warsaw, Poland \\ Correspondence: Małgorzata Rumińska, Department of Paediatrics and Endocrinology, Medical University of Warsaw, Żwirki i Wigury 63A, 02-091 Warsaw, Poland, \\ tel.: + 482231795 63, e-mail: mruminska@wum.edu.pl
}

\begin{abstract}
Obesity is a serious health problem responsible for lipid and carbohydrate metabolism disorders, metabolic syndrome, hypertension, fatty liver and endocrine disorders, which are increasingly common in the paediatric population. Insulin resistance is the underlying cause of these complications. It is described as a state of reduced target tissue sensitivity to insulin despite its normal or increased serum levels. The hyperinsulinaemic-euglycemic clamp is the "gold standard" in the diagnosis of insulin resistance, but since it is time-consuming, costly and technically challenging, the method is used only in scientific research. There are several simple, indirect indicators to assess insulin resistance, which are estimated from fasting glucose and insulin values or from the data obtained in the oral glucose tolerance test, with homeostasis model assessment of insulin resistance (HOMA-IR) being the most popular tool. Despite many clinical trials, there are still no clear standards for the diagnosis and treatment of insulin resistance in children and adolescents. The management is based on the principles of a healthy lifestyle. A properly balanced diet, increased physical activity and weight loss contribute to improved insulin sensitivity. Health education, as well as prevention and treatment of childhood obesity seem to be crucial for preventing insulin resistance and related complications.
\end{abstract}

Keywords: insulin resistance, obesity, HOMA-IR, children

Streszczenie Otyłość jest poważnym problemem zdrowotnym, odpowiedzialnym za rozwój zaburzeń gospodarki lipidowej i węglowodanowej, zespołu metabolicznego, nadciśnienia tętniczego, stłuszczenia wątroby czy zaburzeń endokrynologicznych, które występują coraz częściej w populacji pediatrycznej. U podłoża powstających powikłań leży insulinooporność. Jest to stan zmniejszonej wrażliwości tkanek docelowych na insulinę pomimo jej prawidłowego lub zwiększonego stężenia w surowicy krwi. „Złotym standardem” rozpoznania insulinooporności jest hiperinsulinemiczna euglikemiczna klamra metaboliczna, jednak ze względu na czasochłonność, koszty oraz trudności techniczne metodę tę wykorzystuje się tylko w badaniach naukowych. Istnieje kilka prostych i pośrednich wskaźników oceniających insulinooporność, wyliczonych na podstawie wartości stężeń glukozy i insuliny na czczo lub w teście doustnego obciążenia glukozą - najpopularniejszym spośród nich jest HOMA-IR (homeostasis model assessment of insulin resistance). Mimo przeprowadzenia wielu badań klinicznych nadal brak jest jednoznacznych standardów postępowania w rozpoznawaniu i leczeniu insulinooporności u dzieci i młodzieży. Podstawę postępowania stanowi wdrożenie zasad zdrowego stylu życia. Na poprawę insulinowrażliwości wpływają prawidłowo zbilansowana dieta, zwiększenie aktywności fizycznej oraz redukcja masy ciała. Edukacja zdrowotna, przeciwdziałanie i leczenie otyłości dziecięcej wydają się mieć zasadnicze znaczenie dla zapobiegania rozwojowi insulinooporności i związanym z nią powikłaniom.

Słowa kluczowe: insulinooporność, otyłość, HOMA-IR, dzieci 


\section{INTRODUCTION}

$\mathrm{T}$ he epidemic of obesity has serious consequences. Since the mid-90s of the last century, there has been a growth in the number of children and adolescents with lipid and carbohydrate metabolism disorders as well as metabolic syndrome. Type 2 diabetes, which until recently was associated only with elderly patients, is increasingly common among young people. In recent years, the prevalence of type $2 \mathrm{di}-$ abetes in children and adolescents has tripled in the United States and some European countries ${ }^{(1)}$. Insulin resistance (IR) is a link between obesity and metabolic disorders and type 2 diabetes. This is a state of reduced target tissue sensitivity to insulin despite its normal or increased serum levels ${ }^{(2-4)}$.

\section{THE MECHANISM OF INSULIN ACTION}

Insulin is an anabolic peptide hormone secreted by the pancreatic $\beta$ cells. Its release is regulated mainly by glucose levels. Certain amino acids and free fatty acids, as well as hormones, such as glucagon, glucocorticoids, growth hormone, catecholamines and leptin, also modulate insulin secretion ${ }^{(2,5)}$.

Although insulin acts primarily on the skeletal muscles, adipose tissue and liver, its receptors are also found in the membranes of all cells in the body. They are composed of two insulin-binding a subunits and two $\beta$ subunits with tyrosine kinase-like activity. Upon insulin binding to the a subunit, the configuration of the receptor changes, the $\beta$ subunit tyrosine residues undergo autophosphorylation, which is followed by phosphorylation of tyrosine residues of the insulin receptor substrate (IRS) proteins, which initiates two main protein activation cascades. The mitogen-activated protein kinase (MAPK) pathway regulates genes that control cell growth and differentiation. The phosphoinositide 3-kinase (PI3K) pathway is responsible for the metabolic action of insulin, such as: synthesis of glycogen, inhibition of gluconeogenesis, increasing cellular glucose catabolism, and enhancing lipogenesis and protein synthesis. This pathway is also responsible for the translocation of glucose transporters (GLUT) from the cytoplasm to the cell membrane ${ }^{(3,5,6)}$.

There are two types of glucose transporters in the human body: GLUTs (14 proteins) and sodium-dependent glucose cotransporters (or sodium-glucose linked transporter, SGLT) (12 proteins). GLUTs are uniporters and are responsible for maintaining glucose homeostasis in the body. More than $90 \%$ of GLUT4 is located inside the cell, and only about $10 \%$ in the membrane ${ }^{(6,7)}$. By translocating GLUT4 to the cell surface, insulin increases intracellular insulin-mediated glucose uptake. The majority of glucose is stored in skeletal muscles. The muscle uptake
SGLTs are a family of sodium-dependent glucose cotransporters. They are responsible for intestinal glucose absorption and renal glucose reabsorption from primary urine $e^{(7)}$.

\section{EPIDEMIOLOGY OF INSULIN RESISTANCE}

The incidence of IR is not precisely known. The overall prevalence rates of IR in eighteen population-based studies among children and adolescents from thirteen countries in Europe, Asia, North and South America ranged between 3.1 and $44 \%$. According to the authors of the review, such discrepancies could be partly explained by the use of different methods for determining IR. IR was more prevalent among obese children. It was up to $68.4 \%$ in obese boys from Austria ${ }^{(8)}$. In an exemplary Polish study by Skoczeń et al. ${ }^{(9)}$, reduced insulin sensitivity was found in $38.3 \%$ of obese children aged $10-16$ years.

\section{AETIOLOGY OF INSULIN RESISTANCE}

Both genetic and environmental factors play a role in IR. It is currently considered that IR is determined by multiple genes. Genotypic factors determine many aspects of metabolism and adipose tissue distribution, while nutritional behaviours may contribute to the genetic predisposition to develop IR in the presence of adverse environmental factors ${ }^{(2,6)}$. Obesity and poor physical activity are the most common causes of $\operatorname{IR}^{(2-4,6)}$. However, IR may also develop in people with normal body mass index $(B M I)^{(3,4)}$. Smoking, alcohol consumption and stress caused by modern lifestyle are also important environmental factors ${ }^{(2,6)}$.

IR also develops in endocrine and metabolic disorders. Hypercortisolaemia, acromegaly, hyperthyroidism, primary hyperparathyroidism, hyperprolactinaemia, and pheochromocytoma are some of the most important of these disorders ${ }^{(2,3,10)}$.

Children of mothers with pre-existing diabetes mellitus (DM) or gestational diabetes mellitus (GDM) and poorly controlled glucose levels during pregnancy, children born small for gestational age (SGA) and those with rapid postpartum weight gain are at risk of $\mathrm{IR}^{(2-4)}$. A physiologically transient reduction in cellular sensitivity to insulin is observed during puberty. This is caused by changes in the growth hormone - insulin-like growth factor 1 (IGF-1) axis and alterations in the content of adipose tissue. In healthy children, this phenomenon should resolve after puberty ${ }^{(4,6)}$.

\section{CLASSIFICATION OF INSULIN RESISTANCE}

Two clinical forms of insulin resistance have been distinguished: hepatic and peripheral. Hepatic IR is characterised by enhanced hepatocyte glycogenolysis and 
gluconeogenesis. In peripheral IR, a decreased ability of cells, skeletal muscle cells in particular, to take up and utilise glucose is observed ${ }^{(6)}$. Reduced sensitivity of adipocytes to insulin results in a reduction of its inhibitory effect on the lipolysis process and increased secretion of free fatty acids (FFA) into the blood, which contributes to IR in other peripheral tissues via the lipotoxicity mechanism ${ }^{(11)}$. The resulting hyperglycaemia is compensated by an increased insulin secretion from the pancreatic beta cells. Persistent hyperinsulinaemia increases the resistance of peripheral cells to insulin. This gives rise to a vicious circle ${ }^{(12)}$.

Three groups of IR have been distinguished based on the mechanism of their development:

1. pre-receptor IR, caused by abnormal structure of insulin molecule, the presence of anti-insulin antibodies or increased insulin degradation;

2. receptor IR, caused by abnormal structure and/or dysfunction of the insulin receptor;

3. post-receptor IR, caused by abnormal cascade activation of proteins or altered structure and function of glucose transporters ${ }^{(10)}$.

The mechanisms underlying IR in obese individuals are complex and not fully understood. Lipid-overloaded adipocytes undergo hypoxia and oxidative stress, which causes activation of the immune system and pro-inflammatory pathways, followed by impairment of intracellular signalling pathways of insulin action. Abdominal obesity is a particularly strong trigger of IR due to the greater hormonal and metabolic activity of visceral adipose tissue compared to the subcutaneous tissue. Hypertrophic adipocytes are the source of multiple adipocytokines that play an important role in the pathogenesis of IR, not only in the adipose tissue itself, but also in other peripheral tissues. An increase in the production and secretion of leptin and resistin is observed, whereas the secretion of adiponectin is reduced. Adipose tissue releases pro-inflammatory cytokines (interleukins IL- 1 and IL-6, tumour necrosis factor $\alpha$, TNF- $\alpha$ ), as well as immune proteins (monocyte chemotactic protein 1, MCP-1). Biologically active proteins secreted by adipocytes via para- and endocrine mechanisms regulate energy homeostasis, influence the carbohydrate and lipid metabolism, and play a role in immune processes. They are responsible for low grade inflammation, which also affects signalling pathways involved in the development of IR. Furthermore, increased lipolytic activity in insulin-insensitive adipocytes results in the release of large amounts of FFAs into the bloodstream, which, by accumulating in hepatocytes and myocytes (lipotoxicity mechanism), inhibit intracellular insulin signal transmission, e.g. by phosphorylation of serine/threonine residues in insulin receptor substrate proteins and glucose uptake resulting from the inhibition of GLUT4 transporter translocation ${ }^{(3,6,11,12)}$. It has been suggested that the accumulation of FFAs in pancreatic beta cells may contribute to their desensitisation and, consequently, reduced insulin secretion and the development of type 2 diabetes $^{(12)}$.

\section{COMPLICATIONS OF INSULIN RESISTANCE}

The major complications of IR include:

1. lipid metabolism disorders;

2. acanthosis nigricans;

3. non-alcoholic fatty liver disease (NAFLD);

4. carbohydrate metabolism disorders;

5. metabolic syndrome;

6. hyperandrogenism.

1. Insulin resistance increases lipolysis, leading to increased FFAs in the blood. Increased hepatic production of very low-density lipoproteins (VLDL) occurs. IR is characterised by an atherogenic lipid profile: increased triglycerides and low-density lipoprotein (LDL) cholesterol and decreased high-density lipoprotein (HDL) cholesterol $^{(2,6)}$.

2. Acanthosis nigricans is characterised by the presence of thickened brown skin with hyperkeratosis, papillomatosis, and hyperpigmentation. It typically affects the neck, armpits, and groin (Fig. 1). The lesions develop as a result of insulin binding to IGF-1 receptors on keratinocytes and skin fibroblasts ${ }^{(13)}$.

3. There are two players in the pathogenesis of NAFLD. IR, which increases lipolysis, triglyceride synthesis and hepatic FFA uptake, is the first player, whereas oxidative stress, which induces progress from simple steatosis to inflammation, is the second one. Formation of fatty cysts in the cytoplasm of hepatocytes, oxidative stress, activation of multiple pro-inflammatory cytokines and apoptotic processes may lead, through non-alcoholic steatohepatitis (NASH), to hepatic fibrosis and cirrhosis. The lesions are irreversible at this stage ${ }^{(14)}$. It was found that $10 \%$ body weight reduction can already improve liver function and ultrasound findings ${ }^{(15)}$.

4. Reduced peripheral glucose uptake and increased glucose production in the liver are observed in IR. The pancreatic beta cells increase insulin production

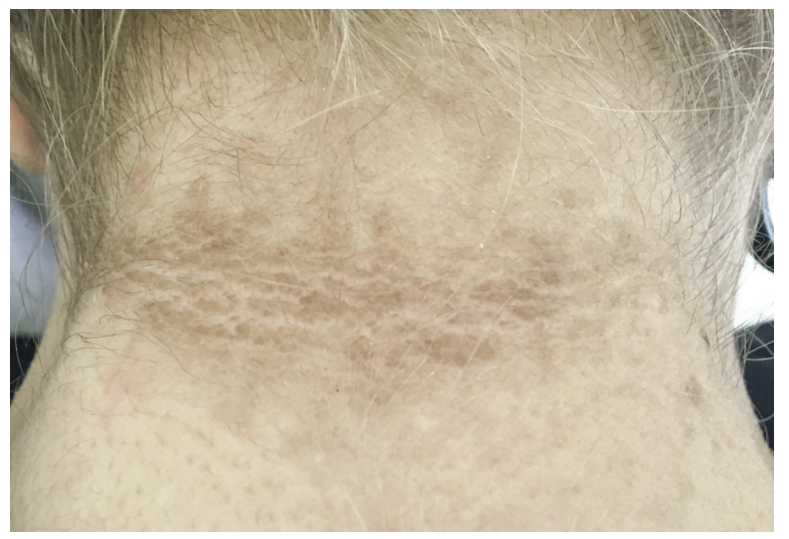

Fig. 1. Acantosis nigricans (own material) 
to maintain normal glucose levels. In chronic IR, pancreatic cell decompensation and death occurs, consequently leading to decreased insulin secretion ${ }^{(2,12)}$. Most children and adolescents with IR have normal blood glucose levels. Reduced pancreatic secretion of insulin induces prediabetes: impaired glucose tolerance (IGT), impaired fasting glucose (IFG), followed by type 2 diabetes $^{(2)}$. Warram et al. ${ }^{(16)}$ showed that the decrease in insulin sensitivity occurs about 10 years before the onset of type 2 diabetes.

5. Insulin resistance underlies metabolic syndrome, which is a pathophysiological reflection of the relationship between central obesity and the accompanying carbohydrate and lipid metabolism disorders, hypertension, proinflammatory and prothrombotic status and the development of atherosclerosis ${ }^{(17)}$. The resulting endothelial structural and functional disorders increase the risk of cardiovascular diseases. The International Diabetes Federation diagnostic criteria (2007) for metabolic syndrome in children and adolescents are presented in Tab. $1^{(18)}$.

6. Insulin resistance may be the cause of premature adrenarche, hirsutism, acne, menstrual disorders or polycystic ovary syndrome (PCOS) in children. The mechanisms underlying hyperandrogenaemia are complex. Hyperinsulinemia increases the adrenal and/or ovarian androgen synthesis, e.g. by increasing the activity of steroidogenesis enzymes (cytochrome p450c17a) ${ }^{(19)}$. Furthermore, insulin stimulates androgen synthesis in ovarian theca cells by increasing the secretion of luteinizing hormone $(\mathrm{LH})^{(19)}$. Excess insulin reduces the hepatic production of insulin-dependent proteins. A decrease in sex hormone binding globulin (SHBG) leads to an increase in free serum androgens ${ }^{(20)}$. The adipose tissue itself contains several steroidogenic enzymes (including $5 a$-reductase) responsible for peripheral conversion of weak androgens into their stronger metabolites. Adipokines and pro-inflammatory cytokines secreted by the adipose tissue are presumably involved in the overproduction of androgens ${ }^{(19)}$.

\section{METHODS FOR THE ASSESSMENT OF INSULIN RESISTANCE}

The diagnostic methods for IR rely on the simultaneous measurement of glucose and insulin levels. The tests are performed under standard conditions (static tests) or after administering glucose and/or insulin in the patient (dynamic tests).

According to the 2010 global group of experts ${ }^{(4)}$, the hyperinsulinaemic-euglycemic clamp is the "gold standard" for IR diagnosis. This method is based on a continuous insulin infusion with a variable glucose infusion rate. The insulin infusion inhibits the production of both endogenous insulin by pancreatic beta cells and glucose by the liver. The test estimates the amount of glucose required to maintain normal glucose levels, with the results expressed as the $M$ value given in $\mathrm{mg} / \mathrm{kg}$ body weight/ min. IR patients require lower doses of glucose infusion to maintain normal blood glucose compared to healthy patients $^{(2,3,6,12,21)}$. There are two other reproducible and reliable methods for assessing IR, i.e. the insulin suppression test (IST) and the frequently sampled intravenous glucose tolerance test (FSIVGTT) ${ }^{(4)}$. Somatostatin (which inhibits endogenous production of insulin and glucagon), glucose and insulin are administered as a continuous infusion in IST. Glucose level in the plateau phase of the test (steady-state plasma glucose, SSPG) is the measure of IR. The higher the SSPG value, the lower the insulin sensitivity ${ }^{(21)}$. In FSIVGTT, the patient receives intravenous glucose, and then glucose and insulin are repeatedly measured over 180 minutes. The $K$ coefficient is calculated from the obtained results using a computer programme. The value of this coefficient $<1.5$ is suggestive of $\mathrm{IR}^{(6,21)}$. The described tests are timeconsuming, inconvenient for the patient and very expensive. Therefore, indirect methods are more commonly used to assess IR.

Oral glucose tolerance test (OGTT) is the most common method for assessing IR. According to Reaven et al. ${ }^{(22)}$, IR is suggested by fasting insulin levels $>15 \mu \mathrm{IU} /$ $\mathrm{mL},>75 \mu \mathrm{IU} / \mathrm{mL}$ at 120 minute time point of the test, or $>150 \mu \mathrm{IU} / \mathrm{mL}$ at any time point of OGTT. Expert groups do not recommend fasting insulin in children for IR assessment due to its low sensitivity. The correlation between OGTT insulin measures and IR has not been well evaluated $^{(4)}$.

Many indirect indicators of insulin resistance have been developed for fasting glucose and insulin values in OGTT. These include insulin/glucose ratio (I/G ratio), fasting glucose to insulin ratio (FGIR), homeostasis

\begin{tabular}{|c|c|c|c|c|c|}
\hline $\begin{array}{c}\text { Age } \\
\text { [years] }\end{array}$ & $\begin{array}{c}\text { Obesity } \\
\text { (waist circumference) }\end{array}$ & Triglycerides & HDL cholesterol & Blood pressure & $\begin{array}{c}\text { Glucose levels } \\
\text { or confirmed type 2 } \\
\text { diabetes }\end{array}$ \\
\hline $6-9$ & $\geq 90 \mathrm{pc}$ & \multicolumn{3}{|c|}{ Metabolic syndrome cannot be diagnosed, but follow-up in risk groups is necessary } \\
\hline $10-15$ & $\begin{array}{c}\geq 90 \mathrm{pc} \text { or criteria for adults } \\
(\geq 94 \mathrm{~cm} \text { for men, } \\
\geq 80 \mathrm{~cm} \text { for women) }\end{array}$ & $\geq 150 \mathrm{mg} / \mathrm{dL}$ & $<40 \mathrm{mg} / \mathrm{dL}$ & $\begin{array}{c}\text { Systolic BP } \geq 130 \mathrm{~mm} \mathrm{Hg} \\
\text { and/or diastolic } \\
\mathrm{BP} \geq 85 \mathrm{~mm} \text { Hg }\end{array}$ & $\begin{array}{c}\mathrm{FPG} \geq 100 \mathrm{mg} / \mathrm{dL} \\
\text { or diagnosed type } 2 \\
\text { diabetes }\end{array}$ \\
\hline \multicolumn{4}{|c|}{ IDF criteria for metabolic syndrome for adults } \\
\hline \multicolumn{4}{|c|}{ BP - blood pressure; FPG - fasting plasma glucose; HDL - high density lipoprotein; $\mathbf{p c}$ - percentile. } \\
\hline
\end{tabular}

Tab. 1. International Diabetes Federation (IDF) criteria for metabolic syndrome in children and adolescents (2007) $)^{(18)}$ 
model assessment of insulin resistance (HOMA-IR), quantitative insulin sensitivity check index (QUICKI), or the Matsuda (oral glucose insulin sensitivity, OGIS) and Belfiore's indices calculated from the data obtained by OGTT. The appropriate formulas are presented in Tab. $2^{(2,3)}$.

In the paediatric population, the values for individual static tests that would define IR in children and adolescents have not been clearly set. This may be partly due to the age-related differences in tissue sensitivity to insulin in children. Furthermore, there are no studies involving a population of children large enough to determine the thresholds for IR, and a single measurement technique and long-term studies to determine the presence of IR complications with cut-off values are missing. In adults, the values indicative of IR are $>2.1$ for HOMA-IR ${ }^{(23)}$; $>0.3$ for $\mathrm{I} / \mathrm{G}^{(6)} ;<0.34$ for QUICKI $^{(23)} ;<7.3$ for the Matsuda index ${ }^{(23)}$.

HOMA-IR is the most popular tool for assessing IR. However, the cut-off points for IR have not been clearly defined in children. Keskin et al. ${ }^{(24)}$ showed that the HOMA-IR index is more reliable in the diagnostics of IR than the FGIR and QUICKI indexes, with a result $>3.16$ indicative of IR. According to Kurtoğlu et al. ${ }^{(25)}$, there are different cut-off points depending on gender and puberty status. The HOMA-IR values indicative of IR are 2.67 and 2.22 in prepubertal boys and girls compared to 5.22 and 3.82 in pubertal boys and girls, respectively. Shashaj et al. ${ }^{(26)}$ determined HOMA-IR cut-off points for cardiometabolic risk factors (increased total cholesterol and/or triglycerides, and/or reduced HDL cholesterol, IGT, and increased alanine aminotransferase) in the population of Caucasian children and adolescents. The $75^{\text {th }}$ percentile for HOMA-IR was 3.02 for the total study group, 1.68 for children with normal body weight, and 3.42 for obese children. In the case of other indirect methods, the following values are indicative of IR in children: Belfiore's index $>1.27^{(6)}$, FGIR $<7^{(24)}$.

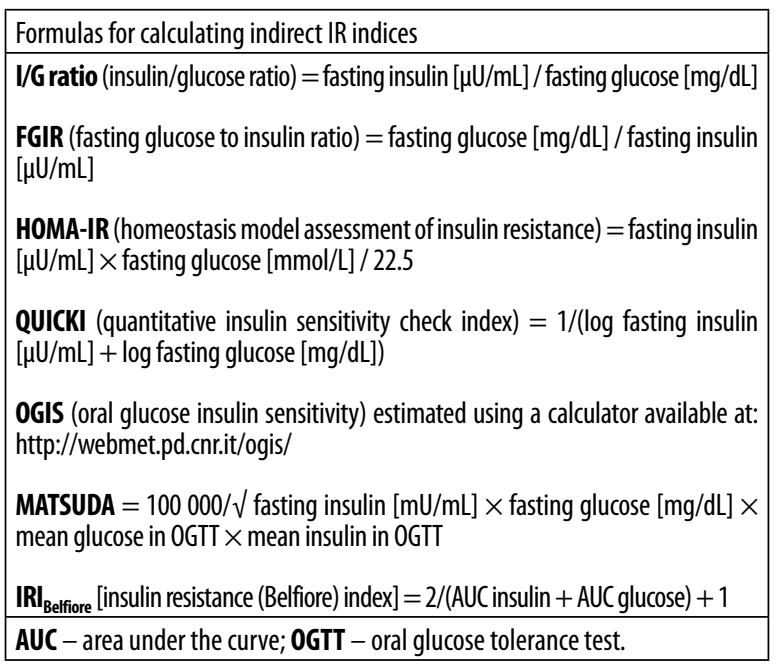

Tab. 2. Selected indirect methods for insulin resistance assessment ${ }^{(2,3)}$
There are no clear criteria for defining IR in children and adolescents. The clinical trials conducted so far lack repeatability and consistency of results. Indirect methods, including fasting insulin measurement, are considered of little use in the assessment of IR. According to a group of experts ${ }^{(4)}$, clinical screening for insulin resistance in obese children is not justified. For these children, interventions aimed at lifestyle modification and weight loss, and consequently improved tissue insulin sensitivity, should be undertaken.

\section{MANAGEMENT IN INSULIN RESISTANCE}

Despite many clinical trials, diagnostic and therapeutic standards for children and adolescents with IR are still missing ${ }^{(4)}$.

The management is based on the implementation of the principles of a healthy lifestyle. A properly balanced diet, increased physical activity and weight loss improve insulin sensitivity. It has been shown in several studies that increased fat intake reduces insulin sensitivity ${ }^{(27,28)}$. Therefore, the diet should include vegetable fats (except for coconut and palm oils), whereas the intake of animal fats and trans-fatty acids (fatty animal products, sweets and fast-food products) should be limited ${ }^{(29)}$.

Reduced energy value of meals, reduced intake of carbohydrates with a high glycaemic index (GI) in particular, is an important element in achieving weight reduction ${ }^{(2)}$. The energy deficit should be determined individually to enable slow yet systematic weight loss (about $0.5-1 \mathrm{~kg} /$ week). However, a diet with a significantly reduced carbohydrate content ( $<45 \%$ of the dietary energy value) and an increased proportion of proteins and fats is not recommended as it may increase the risk of cardiovascular disease, cancer and type 2 diabetes. Since dietary protein exhibits insulinotropic properties, a highprotein diet may increase IR and hyperinsulinaemia. Additionally, a high-protein diet may exert detrimental effects on renal function and proper bone turnover. It is recommended to choose products with a low $(<55 \%)$ and, to a lesser extent, medium (56-69\%) GI, which include most raw vegetables, some fruit, whole grains and legume seeds. Low GI products are associated with a more gradual increase in blood glucose, its slower gastrointestinal absorption, reduced insulin release and prolonged satiety, which may translate into smaller portions of subsequent meals. The GI value is modifiable by various factors, including the degree of fragmentation (higher fragmentation $=$ higher GI), thermal processing (more overcooked product $=$ higher GI), protein content (reduced GI), fat content (a small amount can reduce GI), the presence of seeds and grains in a meal (reduce GI), pickling and fermentation processes (lowering GI), and meal time (the longer the meal time, the more slowly glucose is released into the blood). Also, a high-fibre diet improves cellular insulin sensitivity and promotes weight 
loss. Dietary fibre (the one obtained from cereals in particular) has a positive effect on the intestinal microbiota. Furthermore, short-chain fatty acids (SCFA) formed during bacterial fermentation of dietary fibre have a beneficial effect on glucose tolerance and systemic inflammation. The positive effect on carbohydrate metabolism is attributed to the water-insoluble fibre fraction, which suppresses the absorption of insulinotropic dietary proteins, which in turn translates into reduced tissue resistance to insulin. In IR, it is also very important to maintain clear intervals between meals and to treat all foods (except for water and unsweetened beverages, and possibly green leafy vegetables) as meals that stimulate an increase in glucose levels and insulin secretion. Despite their low GI, most dairy products can also trigger a significant rise in insulin levels due to their high insulin index. Their proportion in the diet of children should be in accordance with the recommendations for the general population (3-4 servings per day). Reduced-fat dairy products with no added sugar seem an optimal choice ${ }^{(29)}$. It is unclear whether the decrease in IR is due to a change in diet, weight loss, or a combination of these factors ${ }^{(4)}$. However, weight loss is considered to be the most effective treatment for $\operatorname{IR}^{(29)}$.

It is emphasised that regular physical activity improves tissue sensitivity to insulin by influencing other mechanisms, independent of weight loss. The optimal form and intensity of exercise has not yet been established ${ }^{(4)}$. Children are recommended to exercise regularly for 30-40 minutes per day ${ }^{(2)}$. Metformin is an approved treatment for children over 10 years of age with prediabetes and type 2 diabetes. The dimethyl derivative of biguanide inhibits hepatic gluconeogenesis, increases glucose transport across the cell membrane by glucose transporters (GLUT) and inhibits lipolysis in adipocytes. Research has confirmed its beneficial effects on improved insulin sensitivity in children with type 2 diabetes and in girls with $\operatorname{PCOS}^{(30,31)}$.

\section{Conflict of interest}

The authors do not declare any financial or personal links to other persons or organisations that could adversely affect the content of this publication or claim rights thereto.

\section{References}

1. Reinehr T: Type 2 diabetes mellitus in children and adolescents. World J Diabetes 2013; 4: 270-281.

2. Ten $\mathrm{S}$, Maclaren $\mathrm{N}$ : Insulin resistance syndrome in children. J Clin Endocrinol Metab 2004; 89: 2526-2539.

3. Tagi VM, Giannini C, Chiarelli F: Insulin resistance in children. Front Endocrinol (Lausanne) 2019; 10:342.

4. Levy-Marchal C, Arslanian S, Cutfield W et al.; ESPE-LWPESISPAD-APPES-APEG-SLEP-JSPE; Insulin Resistance in Children Consensus Conference Group: Insulin resistance in children: consensus, perspective, and future directions. J Clin Endocrinol Metab 2010; 95: 5189-5198.

5. Fu Z, Gilbert ER, Liu D: Regulation of insulin synthesis and secretion and pancreatic beta-cell dysfunction in diabetes. Curr Diabetes Rev 2013; 9: 25-53.

6. Stąpor N, Beń-Skowronek I: Insulinooporność u dzieci. Pediatr Endocrinol Diabetes Metab 2014; 21: 107-115.

7. Magier Z, Jarzyna R: Rola transporterów glukozy w regulacji metabolizmu człowieka. Postepy Biochem 2013; 59: 70-82.

8. van der Aa MP, Fazeli Farsani S, Knibbe CAJ et al.: Populationbased studies on the epidemiology of insulin resistance in children. J Diabetes Res 2015; 2015: 362375.

9. Skoczeń M, Radwański K, Chrzanowska J et al.: Występowanie zaburzeń gospodarki węglowodanowej i lipidowej u dzieci z otyłością prostą w zależności od wieku oraz stopnia otyłości. Endokrynol Ped 2014; 4: 27-36.

10. Grzesiuk W, Szydlarska D, Jóźwik K: Insulinooporność w endokrynopatiach. Endokrynol Otył Zab Przem Mat 2008; 4: 38-44.

11. Yazıcı D, Sezer H: Insulin resistance, obesity and lipotoxicity. Adv Exp Med Biol 2017; 960: 277-304.

12. Pawlak J, Derlacz RA: Mechanizm powstawania oporności na insulinę w tkankach obwodowych. Postepy Biochem 2011; 57: 200-206.

13. Phiske MM: An approach to acanthosis nigricans. Indian Dermatol Online J 2014; 5: 239-249.

14. Chitturi S, Abeygunasekera S, Farrel GC et al.: NASH and insulin resistance: insulin hypersecretion and specific association with the insulin resistance syndrome. Hepatology 2002; 35: 373-379.

15. Ueno T, Sugawara H, Sujaku K et al.: Therapeutic effects of restricted diet and exercise in obese patients with fatty liver. J Hepatol 1997; 27: 103-107.

16. Warram JH, Martin BC, Krolewski AS et al.: Slow glucose removal rate and hyperinsulinemia precede the development of type II diabetes in the offspring of diabetic parents. Ann Intern Med 1990; 113: 909-915.

17. Pacholczyk M, Ferenc T, Kowalski J: Zespół metaboliczny. Część II: patogeneza zespołu metabolicznego i jego powikłań. Postepy Hig Med Dosw 2008; 62: 543-558.

18. Zimmet P, Alberti KG, Kaufman F et al.; IDF Consensus Group: The metabolic syndrome in children and adolescents - an IDF consensus report. Pediatr Diabetes 2007; 8: 299-306.

19. Ibáñez L, Oberfield SE, Witchel S et al.: An international consortium update: pathophysiology, diagnosis, and treatment of polycystic ovarian syndrome in adolescence. Horm Res Paediatr 2017; 88: 371-395.

20. Ibáñez L, Potau N, Zampolli $M$ et al.: Hyperinsulinemia and decreased insulin-like growth factor-binding protein-1 are common features in prepubertal and pubertal girls with a history of premature pubarche. J Clin Endocrinol Metab 1997; 82: 2283-2288.

21. Muniyappa R, Lee S, Chen $\mathrm{H}$ et al.: Current approaches for assessing insulin sensitivity and resistance in vivo: advantages, limitations, and appropriate usage. Am J Physiol Endocrinol Metab 2008; 294: E15-E26.

22. Reaven GM, Brand RJ, Chen YD et al.: Insulin resistance and insulin secretion are determinants of oral glucose tolerance in normal individuals. Diabetes 1993; 42: 1324-1332.

23. Szurkowska M, Szafraniec K, Gilis-Januszewska A el al.: Wskaźniki insulinooporności w badaniu populacyjnym i ich wartość predykcyjna w określeniu zespołu metabolicznego. Przegl Epidemiol 2005; 59: 743-751. 
24. Keskin M, Kurtoğlu S, Kendirci M et al.: Homeostasis model assessment is more reliable than the fasting glucose/insulin ratio and quantitative insulin sensitivity check index for assessing insulin resistance among obese children and adolescents. Pediatrics 2005; 115: e500-e503.

25. Kurtoğlu S, Hatipoğlu N, Mazıcıoğlu M et al.: Insulin resistance in obese children and adolescents: HOMA-IR cut-off levels in the prepubertal and pubertal periods. J Clin Res Pediatr Endocrinol 2010; 2: 100-106.

26. Shashaj B, Luciano R, Contoli B et al.: Reference ranges of HOMA-IR in normal-weight and obese young Caucasians. Acta Diabetol 2016; 53: 251-260.

27. Sunehag AI, Toffolo G, Treuth MS et al.: Effects of dietary macronutrient content on glucose metabolism in children. J Clin Endocrinol Metab 2002; 87: 5168-5178.
28. Weigensberg MJ, Ball GDC, Shaibi GQ et al.: Dietary fat intake and insulin resistance in black and white children. Obes Res 2005; 13: 1630-1637.

29. Jeznach-Steinhagen A (ed.): Żywienie osób z cukrzycą i chorobami towarzyszącymi. Wydawnictwo Lekarskie PZWL, Warszawa 2020.

30. Jones KL, Arslanian S, Peterokova VA et al.: Effect of metformin in pediatric patients with type 2 diabetes: a randomized controlled trial. Diabetes Care 2002; 25: 89-94.

31. Arslanian SA, Lewy V, Danadian K et al.: Metformin therapy in obese adolescents with polycystic ovary syndrome and impaired glucose tolerance: amelioration of exaggerated adrenal response to adrenocorticotropin with reduction of insulinemia/insulin resistance. J Clin Endocrinol Metab 2002; 87: 1555-1559. 